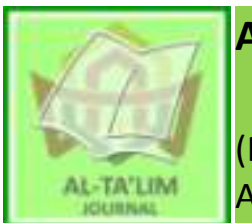

AL-TA'LIM JOURNAL, 25 (2), 2018, (108-116)

(Print ISSN 1410-7546 Online ISSN 2355-7893)

Available online at http://journal.tarbiyahiainib.ac.id/index.php/attalim

\title{
Fairy Tale as a Medium for Children's Character Cooperation Building
}

Received: $07^{\text {th }}$ May 2018; Revised:30 ${ }^{\text {th }}$ June 2018; Accepted: $24^{\text {th }}$ July 2018

Permalink/DOI: http://dx.doi.org/10.15548/jt.v25i2.458

Inaad Mutlib Sayer *)

University of Human Development, Kurdistan Region, Iraq

E-Mail: inaad.sayer@uhd.edu.iq

\section{Muhammad Kristiawan}

Universitas PGRI Palembang, Indonesia

E-Mail: muhammad.kristiawan@yahoo.co.id

\section{Mediarita Agustina}

SMP Bina Utama, Palembang, Indonesia

E-Mail: agustinamediarita@yahoo.com

*) Corresponding Author

\begin{abstract}
A fairy tale is a fantasy story which gives moral education, and can be one of the media used for character building. One of the values found in a fairy tale is cooperation. Children's character building strategy is done through giving fairy tales, listening to fairy tales, and creating a supportive reading environment. This study aimed at observing the ability of children in identifying the character values found in fairy tales and their ability to implement the values in their daily life. The respondents of this study were 3-4-year-old students of PAUD Pelangi Palembang. The number of the respondents was 15 students. Data mixed research design was used where the data collected through interview, observation and test. The results revealed that the value of cooperation could be effectively implemented through fairy tales. Before they were told fairy tales, the students were reluctant to tidy up their toys after they finished playing together, but after they were given a fairy tale about cooperation, the children enthusiastically cooperated to tidy up their toys, tidy up the class' benches, throw garbage and tidy up the books on the shelf.
\end{abstract}

Keywords: Fairy tale; character building; media for children's character

How to cite: Sayer, I., Kristiawan, M., \& Agustina, M. (2018). Fairy tale as a medium for children's character cooperation building. Al-Ta Lim Journal, 25(2). doi: http://dx.doi.org/10.15548/jt.v25i2.458

\section{INTRODUCTION}

The challenge for educators in Early Childhood Education Programs, like PAUD is to provide a touch of creative, innovative, intelligent education, and fun to the world of early childhood, which has disappeared in modern life (Copple \& Bredekamp, 2009; Currie, 2001; Fantuzzo, Tighe, \& Childs, 2000; Rozalena \& Kristiawan, 2017). In such a context, the children feel happy while studying and they could gain the essence of learning that is to build a character. Storytelling is considered a good technique to provide such education. Storytelling is one of the oldest forms of education. It had been used by people from different races to pass their culture, history and traditions from one generation to another.

Research examined the implementation of storytelling in the classroom has shown that storytelling can help children develop emotional intelligence as well as better self-awareness and awareness of others (Mello, 2001), healthy self-concept and sense of identity (Paley, 2009), enhanced imagination (Kasahara \& Ochi, 2006; Storm, 1999), human morality (Gintis, Henrich, Bowles, Boyd, \& Fehr, 2008; Tomasello, 2016), and cultural sensitivity (Resnicow, Soler, Braithwaite, Ahluwalia, \& Butler, 2000). 
One of the media of storytelling used in education in general and in the classroom in particular is fairy tales. A fairy tale is a story, often intended for children, that features fanciful and wondrous characters such as elves, goblins, wizards, and even, but not necessarily, fairies. The term "fairy" tale seems to refer more to the fantastic and magical setting or magical influences within a story, rather than the presence of the character of a fairy within that story (Silverman, 2004). Fairy tale is a learning method that is believed to contribute to the learning and planting the values in early childhood characters. Fairy tales contain the values of philosophy and wisdom that can be learned by children in a funny way, at the same time the children will not feel patronized. According to Bacchilega, (2010); Zipes (2012), fairy tales are "all forms of narrative, written, or oral, which have come to be handed down through the years".

Therefore, fairy tales are all forms of stories that have always existed and recounted from generation to generation. Priyono, Nusantara, \& Wijaya (2001) argues that fairy tale is a fantasy or a story that is ridiculous and unreasonable but a benefit can be drawn from. Thus, the story contained in the fairy tale is an imaginary story which is sometimes beyond common sense. Rukiyah (2018) state that fairy tale is a common story that tells about fairy world. The tale tells the good that will always prevail against evil. This genre of story passed down from generation to generation and it became part of a culture. The tale contains events about society, history and natural phenomena as well as hope for change (Mahdiani, 2012; Rosada, 2016; Sulistianingsih, 2017).

According to Carr (2001) fairy tale is a story that contains frightening stories, such as the evil stepmother, children baked in the oven, and ferocious wolves. Nevertheless, the stories are favored by children because they give children the opportunity to imagine by depicting those events into fantasy. Although fairy tales encompass a variety of story types, they all share two elements: "the acceptance of the fantastical as plausible and the ability to assert a moral lesson on individuals of societies" (Bettelheim, 2010; Lester, 2015).

Fairy tales are believed to have an influential role in children's education since they expose a primitive way of thinking which is very close to the way of thinking children have (Hohr, 2000; Singhal, 2013). They "have the ability to affect the virtues, expectations, pastimes, and aspirations of society members" (Lester, 2015). In Early Childhood Education (PAUD), fairy tales are used as a reliable stimulus to advise children. Advice is conveyed by telling a story that contains a message or wisdom as its morale. Children are directed to deepen a fairy tale to then indirectly invited to imitate the message contained therein as a character that will be the foundation later when he grew up. The aim of the present study is to examine the impact of fairy tales as an educational medium on building cooperative characters in children (Juwita, Tiatri, \& Hastuti, n.d.; Kemal \& Huda, 2016; Kurniasih, 2016).

\section{Character}

The term character is identical to the term manners good or bad habit (Nur, 2013; Rusydiyah, 2014; Susanti, 2013). According to (Wulandari \& Kristiawan, 2017) character education is a national movement to create a school that fosters an ethical, responsible, and caring young generation. Character education is not only about what is true and what is wrong; it is an attempt to inculcate good habituation so that students are able to behave and act on the values that have become personality (Berkowitz \& Bier, 2004, 2005; Lickona, Schaps, \& Lewis, 2002; Noddings, 2002). Kristiawan (2015) states that Indonesia needs revitalization and strengthening of characters of human resources. And this can be done through education. Kristiawan, Ahmad, Tobari, \& Suhono (2017) explain that the process of character formation starts from the introduction of both good and bad behavior, and habituation behavior in everyday life. Morals distinguish one's self from another person. 
The Directorate General of the Ministry of National Education explains that character is the way of thinking and behaving that characterizes each individual to live and cooperate within the family, society, nation and state (Suhaimi, 2016). Individuals with good character are individuals who can make decisions and are prepared to account for any consequences of the decisions they make. Characters are also often equated with morals. In a general sense, morality is the value that governs human life, (Davidson, 2010; Zigon, 2007). It can be concluded that character is an individual's way of thinking and behaving that distinguishes him/her from others in life on the personal and social levels.

\section{The Values of Fairy Tale}

The tale is one of the forms of folklore. According to Sulistyarini (2011), folklore contains the noble value of the nation, especially the values of moral character and moral teachings. If the folklore is studied in terms of moral values, it can be divided into individual moral values, social moral values, and religious moral values. The individual moral values include (1) obedience, (2) courage, (3) willing to sacrifice, (4) honesty, (5) fairness and wisdom, (6) respect and appreciation, (7) hard work, (8) keeping a promise, (9) knowing repayment, (10) being humble, and (12) being careful in acting. Social moral values include (1) cooperating, (2) loving, (3) affection, (4) harmony, (5) giving advice, (6) caring about the fate of others, and (7) liking to pray for other people. Meanwhile, religious moral values include (1) believing in God's power, (2) believing in God, (3) submitting to God or putting up trust, and (4) asking forgiveness of God.

Fairy tales can also be used as an effort to hone emotions, foster the imagination and increase the critical power of children. In general, fairy tales carry a positive and educative mission (Parmini, 2015; Purwaningsih, 2012; Soetantyo, 2013). Through fairy tales, the child's emotions are expected to be under control, the child's imagination can flourish, and the child can think critically. Nur (2013) states that storytelling can be an interesting art. Through storytelling children get different cultures and lifestyles. Children will explore new worlds and engage them in plot and character visualizations (Robin \& Pierson, 2005; Simmons, 2006; Tsou, Wang, \& Tzeng, 2006). Fairy tales "speak the language children understand and show the complicated world before the children's innocent eyes in a comprehensible manners by their simplicity, clear definition of good and evil, understandable incidents and beauty of their language". Besides, they deliver "the information about social values, traditions and basic human interactions, information of the ethical origin and information about a moral dimension of the human life".

\section{Strategy of Building Character through Fairy Tale}

Habsari (2017) claims that storytelling is one of the strategies of learning, especially at the level of basic education. Not only in school, is storytelling also an alternative way of learning that can be applied outside the school, such as at home or family. Through fairy tales, parents, grandparents, and other family members can convey moral messages to their sons and daughters. The formation of character through fairy tales in PAUD schools can be done by the teacher's reading an interesting story in front of the class at least once a week, or 15 minutes every day before school starts. Outside the school, character education can be achieved by following different techniques, such as (1) parents or relatives read the child a fairy tale before going to bed or at leisure time; (2) children are provided with interesting fairy tales books to read; (3) parents ask the child questions to see the child's understanding and memory of fairy tales; and (4) parents take children to bookstores and give them the opportunity to purchase their favorite books, including fairy tales. 


\section{METHOD}

The subjects of the study were 15 students from PAUD schools ( 8 males and 7 females). They were 3-4 years old. The material of the study consisted of a fairy tale entitled "Working Ants" (Appendix 1). The story of the fairy tale is about ants; how they cooperate to build their nests and collect food. They work hard without complaining and they support each other passionately. They have moral obligations towards each other. The researchers made the children listen to the tale on October 05, 2017, after observing their behavior for two days (October 03-04, 2017). The researchers observed the behavior of the children again for four days after the storytelling (October 06-09, 2017.

Then, they compared the children's behavior as far as cooperation is concerned before the storytelling with their behavior after the storytelling to examine whether there is any influence of the plot and the characters of the story on the children's characters or not. The researchers used animals' pictures while narrating the fairy tale to support the story and to attract the attention of the children to the moral lesson of the story, viz. cooperation. The data were collected by two techniques: observation and interviews. As stated above, the experimental groups was observed for six days (2 days before the storytelling and 4 days after the storytelling). In addition, the researchers made interviews with the parents of the students before and after the storytelling in order to gather data about the students' behavior inside and outside school and to ensure the reliability of the research data. The qualitative method rather than the quantitative method was used to describe and discuss the results of the study experiment.

\section{RESULTS AND DISCUSSIONS}

The data collected from the interviews and observation reveals that the children were reluctant to cooperate during the first day and the second day of the experiment. When the children were asked to help their teacher dry up the dustbin or to tidy up their toys after they finish playing together, only four students showed cooperation on the first day and only five students did so on the second day; the others just looked at them (Table 1 and Picture 1).

Table 1. Observation Results before Telling the Fairy Tale

\begin{tabular}{llrc}
\hline No & Name & Day 1 & Day 2 \\
\hline 1 & Kirana Aruna & $\sqrt{ }$ & $\sqrt{ }$ \\
2 & Siti Fadia & & \\
3 & Aulia & $\sqrt{ }$ & $\sqrt{ }$ \\
4 & Atiqah & & \\
5 & Emir & & \\
6 & Farhantio & & \\
7 & Inaya Valencia & $\sqrt{ }$ & $\sqrt{ }$ \\
8 & Kalila Saskirana & & \\
9 & M. Athallah & & $\sqrt{ }$ \\
10 & M. Rafindra & & \\
11 & M. Haziq & & \\
12 & Nabil Putranto & $\sqrt{ }$ \\
13 & Raja Zilldjiandra & $\sqrt{ }$ & \\
14 & Syahquita Fatimah & & \\
15 & Mahanta Manggala & & \\
\multicolumn{2}{c}{ Total } & $\mathbf{4}$ & $\mathbf{5}$ \\
\hline
\end{tabular}

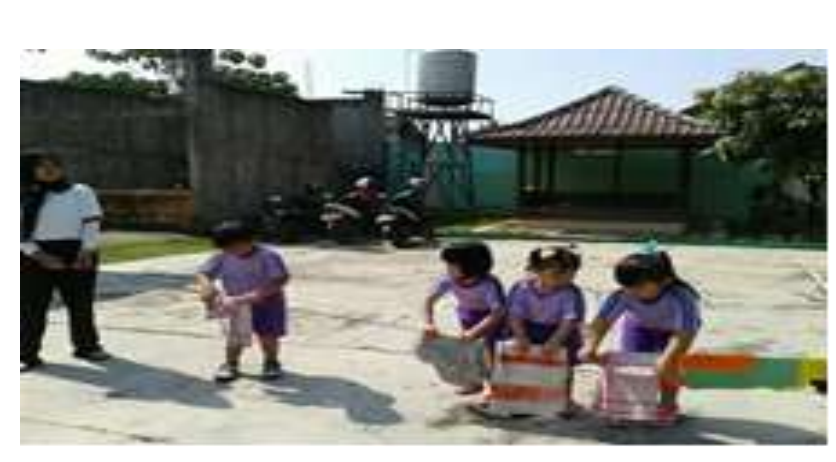

Picture 1. Teacher Asks Children to Help Dry the Dirt Shine

On the third day of the experiment, the researchers plunged directly in telling the children the fairy tale and explaining its moral value. They kept repeating the fairy tale for four days while testing the students in its content. The students gave good responses to the researchers' questions and they remembered the content of the tale and its moral lesson. The results of the post storytelling observation showed that the children were very enthusiastic to work together and cooperate when they were asked to tidy up the messy toys, tidy up the class benches, throw garbage and tidy up the books on the shelf (Table 2 and Pictures $2 \& 3$ ). 
Besides, the children's parents who were interviewed by the researchers after the implementation of the fairy tale technique in the class assured that their children's behavior changed and the children became more cooperative. One of the interviewed mothers said, "My child started to help me when I cook and tidy up her toys after she finishes playing at home".

Table 2. Observation Results after Telling

\begin{tabular}{clc}
\multicolumn{3}{c}{ the Fairy Tale } \\
\hline No & Name & Day 7 \\
\hline 1 & Kirana Aruna & $\sqrt{ }$ \\
2 & Siti Fadia & $\sqrt{ }$ \\
3 & Aulia & $\sqrt{ }$ \\
4 & Atiqah & $\sqrt{ }$ \\
5 & Emir & $\sqrt{ }$ \\
6 & Farhantio & $\sqrt{ }$ \\
7 & Inaya Valencia & $\sqrt{ }$ \\
8 & Kalila Saskirana & $\sqrt{ }$ \\
9 & M. Athallah & $\sqrt{ }$ \\
10 & M. Rafindra & $\sqrt{ }$ \\
11 & M. Haziq & $\sqrt{ }$ \\
12 & Nabil Putranto & $\sqrt{ }$ \\
13 & Raja Zilldjiandra & $\sqrt{ }$ \\
14 & Syahquita Fatimah & $\sqrt{ }$ \\
15 & Mahanta Manggala & $\mathbf{1 5}$ \\
\hline
\end{tabular}

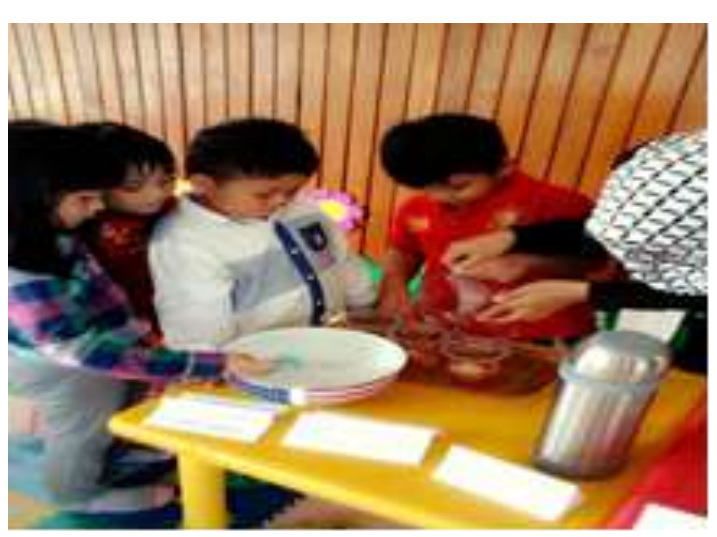

Picture 2. Teachers and Children

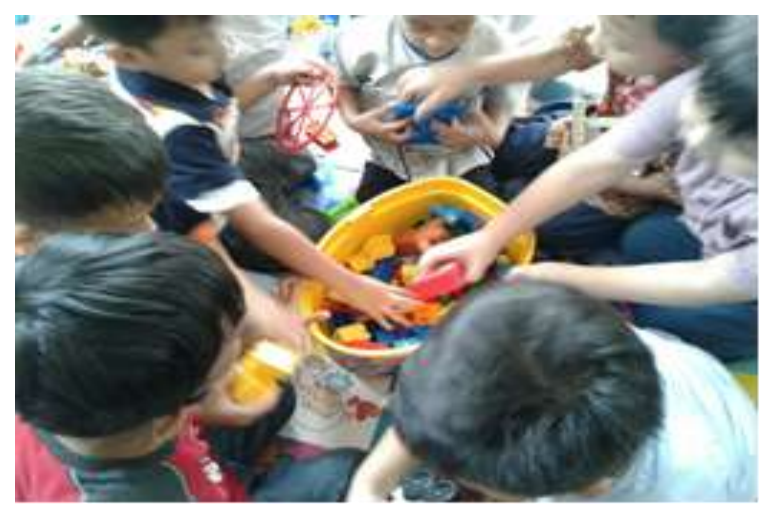

Picture 3. Enthusiastic Children Spruce the Toys into the Toy Container
The children who learned to cooperate and do tasks in teamwork managed to win various competitions at sub-district and city levels (Pictures 4 and 5). This actually emphasizes the importance and necessity of building cooperative characters in early childhood.

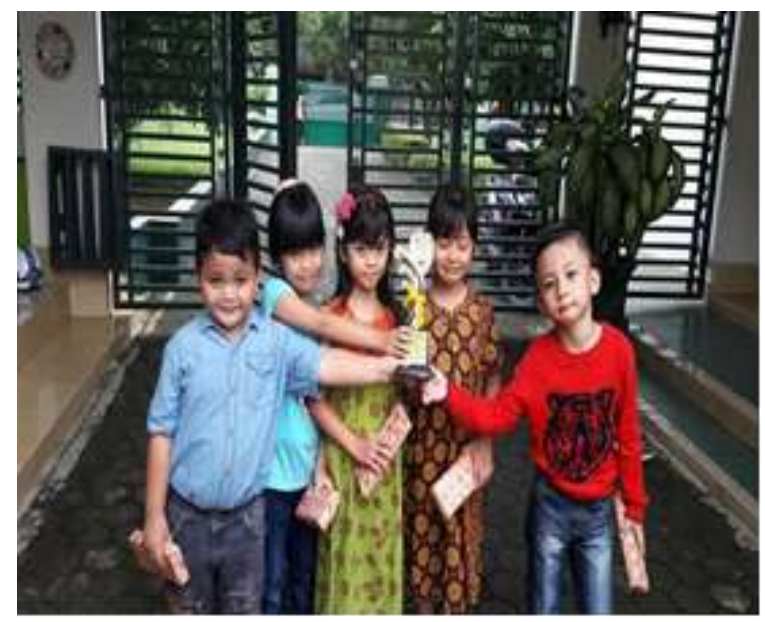

Picture 4. Winner of Motion and Song Competition of Sukarami Sub-District Children

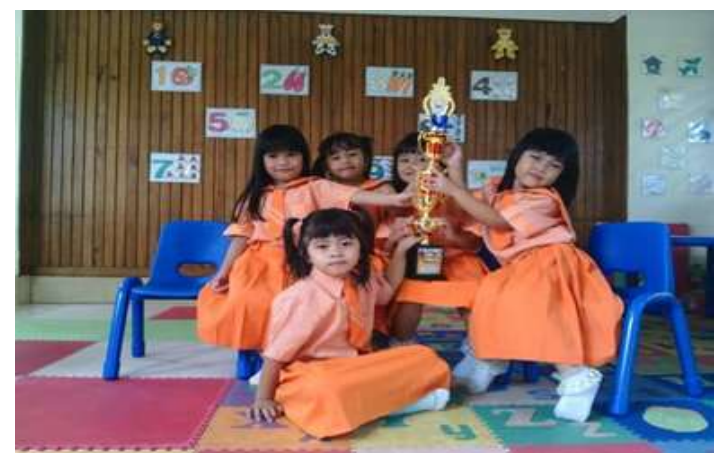

Picture 5. Champion 3 Modern Dance PAUD Level in Palembang

The analysis of the results obtained demonstrated that there was an improvement in the characters of the children. This is in accordance to Khorida \& Fadlilah (2013); Mualifatu \& Lilif (2013) that one of the benefits of storytelling method is to form a child's character. The findings of this study are supported by several studies.

For instance, Mardianto (2015) qualitative study, which was conducted on 7-8 years old Indonesian students, revealed that the interactive method of fairy tales contributes positively to the development of 
the honest character of the students. According to Connery, John-Steiner, \& Marjanovic-Shane (2010), "the characters, their actions and their reward" in fairy tales "lead to the development of moral issues". Lepin (2012) believes that fairy tales constitute a successful tool to "establish and strengthen the morality in a child's life from his early age where hundreds of orders and warnings failed". Through the method of fairytale, the children can directly capture the moral message, which can make children desire to imitate the characters in the story. When children read or listen to stories, they can imagine the good characters by looking directly at the pictures that exemplify them. The benefits of stories for early childhood are (1) establishing inner contact between the child, the teacher and the parents, (2) constituting the child's message media, (3) providing the fantasy education of the child, (4) training the child's emotions, (5) helping the process of self-identification, (6) enriching the inner experience, (7) giving entertainment or attracting children's attention, (8) shaping the child's character (Fadlillah, 2016).

It is not enough to build the cognitive aspects of children's character. It is essential to integrate the affective and psychomotor aspects as well. In addition to "knowing" (cognitive) the characters in the fairy tale, the child must "feel" (affective) their behaviors and the outcome (karmapala) of their role in the story. Telling fairy tales to children must be done properly to form good character in children. Taking into account the logic of the story and the correct selection of words and sentences, because it is "carving" the child's character. Therefore, educators and parents should be able to distinguish clearly between the delivery of an imaginative story and a realistic story.

\section{CONCLUSION AND RECOMMENDATION}

Based on the results of the present research it can be concluded that it is very important to instill good values in the child's character since early childhood. The perceived impact of building a noble character in early childhood will affect every child's daily behavior in its development to maturity. If a child gets sufficient character education from both teachers and parents, then the child will grow into the next generation armed with a noble character. In addition, the character of the child is developed from the development of the potential of the child. Thus, it can be said that the method of storytelling of fairy tales is very good to use because it can instill character and provide positive benefits for children's development, especially on the moral, emotional and social levels.

It is recommended that PAUD educators incorporate a variety of fairy tales to the curriculum of children education as fairy tales are proved influential medium in building children's personalities. Moreover, they should support the fairy tales with different media, such as pictures, videos etc. in order to attract the attention of the children and avoid boring educational environment. It is also recommended that teachers narrate the stories of fairy tales with love and affection and act the role of the child parent at school. Teachers can invite children to tidy up their toys while the fairy tale. For example, if the child's toy has a nickname, tell him/her that the toy character will feel good when it returns to its original place after they finish playing. Create a smoothing toy is something interesting and it's not a hassle. Furthermore, education at school is not enough to cultivate a positive, noble, cooperative character in children. Therefore, parents should play their role to help teachers educate children in this direction. They can exemplify positive things to children at home, but they should always provide understanding if the child resists to learn. They need to observe the child as well to see when there is improvement in its behavior and when it needs feedback.

\section{REFERENCES}

Bacchilega, C. (2010). Postmodern fairy tales: Gender and narrative strategies. University of Pennsylvania Press. 
Berkowitz, M. W., \& Bier, M. C. (2004). based character education. The Annals of the American Academy of Political and Social Science, 591(1), 72-85.

Berkowitz, M. W., \& Bier, M. C. (2005). What works in character education: A research-driven guide for educators. Washington, DC: Character Education Partnership.

Bettelheim, B. (2010). The uses of enchantment: The meaning and importance of fairy tales. Vintage.

Carr, M. (2001). Assessment in early childhood settings: Learning stories. Sage.

Connery, M. C., John-Steiner, V., \& Marjanovic-Shane, A. (2010). Vygotsky and creativity: A culturalhistorical approach to play, meaning making, and the arts (Vol. 5). Peter Lang.

Copple, C., \& Bredekamp, S. (2009). Developmentally appropriate practice in early childhood programs serving children from birth through age 8 . ERIC.

Currie, J. (2001). Early childhood education programs. Journal of Economic Perspectives, 15(2), 213-238.

Davidson, C. (2010). Conversations as Signifiers: Characters on the Margins of Morality in the First Three Novels of Frances Burney. Partial Answers: Journal of Literature and the History of Ideas, 8(2), 277-304.

Fadlillah, M. (2016). Edutainment Pendidikan Anak Usia Dini: Menciptakan Pembelajaran Menarik, Kreatif dan Menyenangkan. Prenada Media.

Fantuzzo, J., Tighe, E., \& Childs, S. (2000). Family Involvement Questionnaire: A multivariate assessment of family participation in early childhood education. Journal of Educational Psychology, 92(2), 367.

Gintis, H., Henrich, J., Bowles, S., Boyd, R., \& Fehr, E. (2008). Strong reciprocity and the roots of human morality. Social Justice Research, 21(2), 241253.

Habsari, Z. (2017). Dongeng sebagai pembentuk karakter anak. Bibliotika: Jurnal Kajian Perpustakaan Dan Informasi, 1(1), 21-29.

Hohr, H. (2000). Dynamic aspects of fairy tales: Social and emotional competence through fairy tales. Scandinavian Journal of Educational Research, 44(1), 89-103.

Juwita, S., Tiatri, S., \& Hastuti, R. (n.d.). Program Identifikasi Tema Dongeng Untuk Meningkatkan Pemahaman Tema Moral Pada Siswa Kelas Lima di Sekolah Dasar. Jurnal Psikologi, 44(3), 167-176.

Kasahara, Y., \& Ochi, K. (2006). The effect of enhanced imagination strategy on eyewitness memory recollection. The Japanese Journal of Criminal Psychology, 44, 9-17.

Kemal, I., \& Huda, N. (2016). Peningkatan Kemampuan Berbicara Anak Melalui Mendongeng Pada Kelompok B di TK Al-Ikhlas Lamlhom Kecamatan Lhoknga Aceh Besar. Jurnal Buah Hati, 1(2).

Khorida, M. F. L. M., \& Fadlilah, M. (2013). Pendidikan Karakter Anak Usia Dini. Jogjakarta: Ar-Ruzz Media.

Kristiawan, M. (2015). A Model of Educational Character in High School Al-Istiqamah Simpang Empat, West Pasaman, West Sumatera. Research Journal of Education, 1(2), 15-20.

Kristiawan, M., Ahmad, S., Tobari, T., \& Suhono, S. (2017). Desain Pembelajaran SMA Plus Negeri 2 
Banyuasin III Berbasis Karakter Di Era Masyarakat Ekonomi ASEAN. Iqra': Jurnal Kajian Ilmu Pendidikan, 2(2), 403-432.

Kurniasih, S. (2016). 6 Peningkatan kecerdasan linguistik melalui mendongeng cerita rakyat (penelitian tindakan di TK B Paud Dahlia, Lampung Selatan Tahun 2016). Nusantara of Research, 3(2), 121128.

Lepin, M. (2012). Fairy tales in teaching English languge skills and values in school stage I. Tartu Ülikool.

Lester, A. J. (2015). The Impact of Traditional and Modern Fairy Tales on Society and Its Individuals.

Lickona, T., Schaps, E., \& Lewis, C. (2002). Eleven principles of effective character education.

Mahdiani, T. F. (2012). Pengaruh Dongeng Dan Bermain Peran Dalam Mengembangkan Empati Pada Anak Usia Dini: Universitas Muhammadiyah Surakarta.

Mardianto, M. (2015). The Effect of fairytale interactive method for improving the honest character on children ages 7-8 years of elemntary students at mis Mutiara Aulia Deli Serdang discrit of North Sumatera. IOSR Journal of Humanities and Social Science, 0104.

Mello, R. (2001). The Power of Storytelling: How Oral Narrative Influences Children's Relationships in Classrooms.

Mualifatu, K., \& Lilif, M. F. (2013). Pendidikan Karakter Anak Usia Dini. Yogyakarta: Ar-Ruzz Media.

Noddings, N. (2002). Educating moral people: A caring alternative to character education. ERIC.
Nur, H. (2013). Membangun karakter anak melalui permainan anak tradisional. Jurnal Pendidikan Karakter, (1).

Paley, V. G. (2009). A child's work: The importance of fantasy play. University of Chicago Press.

Parmini, N. P. (2015). Eksistensi cerita rakyat dalam pendidikan karakter siswa SD di Ubud. Journal of Bali Studies, 5(2).

Priyono, K., Nusantara, A. A., \& Wijaya, T. (2001). Terampil Mendongeng. Gramedia Widiasarana Indonesia (Grasindo).

Purwaningsih, E. (2012). Keluarga dalam mewujudkan pendidikan nilai sebagai upaya mengatasi degradasi nilai moral. Jurnal Pendidikan Sosiologi Dan Humaniora, 1(1).

Resnicow, K., Soler, R., Braithwaite, R. L., Ahluwalia, J. S., \& Butler, J. (2000). Cultural sensitivity in substance use prevention. Journal of Community Psychology, 28(3), 271-290.

Robin, B., \& Pierson, M. (2005). A multilevel approach to using digital storytelling in the classroom. In Society for Information Technology \& Teacher Education International Conference (pp. 708-716). Association for the Advancement of Computing in Education (AACE).

Rosada, U. D. (2016). Memperkuat karakter anak melalui dongeng berbasis media visual. Jurnal CARE (Children Advisory Research and Education), 4(1), 42-49.

Rozalena, R., \& Kristiawan, M. (2017). Pengelolaan pembelajaran paud dalam mengembangkan potensi anak usia dini. JMKSP (Jurnal Manajemen, Kepemimpinan, Dan Supervisi Pendidikan), 2(1).

Rukiyah, R. (2018). Dongeng, mendongeng, dan manfaatnya. Anuva, 2(1), 99-106. 
Rusydiyah, E. F. (2014). Character education through the constructivist design of islamic education subject at elementary school pembangunan Jaya II in Gedangan Sidoarjo. Al-Ta Lim Journal, 21(3), 227-238.

Silverman, Y. (2004). The story within-myth and fairy tale in therapy. The Arts in Psychotherapy.

Simmons, A. (2006). The story factor: Inspiration, influence, and persuasion through the art of storytelling. Basic books.

Singhal, A. (2013). Introduction: Fairy tales to digital games: the rising tide of entertainment education. Critical Arts, $27(1), 1-8$.

Soetantyo, S. P. (2013). Peranan Dongeng dalam pembentukan karakter siswa Sekolah Dasar. Jurnal Pendidikan, 14(1), 44-51.

Storm, B. (1999). The enhanced imagination: Storytelling. Power to Entrance Listeners. Storytelling, 2(2).

Suhaimi, S. (2016). Identifying characters of "Where Angel Fear to Tread Novel" in teaching literary work. Al-Ta Lim Journal, 23(2), 139-145.

Sulistianingsih, E. (2017). The effectiveness of learning model based digital storyTelling to improve students'emotional intelegence. Jurnal
Penelitian Pendidikan, 34(2), 121126.

Sulistyarini, D. (2011). Nilai moral dalam cerita rakyat sebagai sarana pendidikan budi pekerti. Konggres Budaya Jawa V. Surabaya, 20-30.

Susanti, R. (2013). Penerapan pendidikan karakter di kalangan mahasiswa. $\mathrm{Al}-\mathrm{Ta}$ Lim Journal, 20(3), 480-487.

Tomasello, M. (2016). A natural history of human morality. Harvard University Press.

Tsou, W., Wang, W., \& Tzeng, Y. (2006). Applying a multimedia storytelling website in foreign language learning. Computers \& Education, 47(1), 1728.

Wulandari, Y., \& Kristiawan, M. (2017). Strategi sekolah dalam penguatan pendidikan karakter bagi siswa dengan memaksimalkan peran orang tua. JMKSP (Jurnal Manajemen, Kepemimpinan, Dan Supervisi Pendidikan), 2(2).

Zigon, J. (2007). Moral breakdown and the ethical demand: A theoretical framework for an anthropology of moralities. Anthropological Theory, 7(2), 131-150.

Zipes, J. (2012). Fairy tales and the art of subversion. Routledge. 